\title{
Molecular docking and molecular dynamics simulation of the anticancer active ligand from Mimosa pudica to the Fibronectin Extra Domain A (EDA).
}

\author{
Mayank Kohli ${ }^{1}$, Dr.Kamatchi $C^{1}$., Dr. Kiran $\operatorname{Kumar}^{1}$, Dr. Shivaji Bole ${ }^{1 *}$ \\ 1.Department of Biotechnology, The Oxford College of Science, Bengaluru-Karnataka, India
}

\section{Corresponding author:}

* Shivaji B Bole

Associate Professor,

PG Dept of Biotechnology,

The Oxford College of Science, Bangalore. India.

E-mail: shivajibio@gmail.com

Ph: +919739759465

\section{Abstract:}

Mimosa pudica was observed to have many useful characters the main aim of the experiment is to strengthen the multiple potential value of M. Pudica L. To study its secondary metabolites antioxidant, anti-cancerous, GCMS and in-silico studies. In general, the methanol method is employed for obtaining leaf extracts. The preliminary phytochemical screening of the $M$. pudica leaf extract showed the presence of bioactive components such as terpenoids, flavonoids, glycosides, alkaloids, quinines, phenols, tannins, saponins, and coumarins. An attempt is made to check the anticancer activity towards the cancer cell line A549 (Lung cancer cells) by MTT assay. For the identification of the compounds and to obtain its structure the crude extract is analyzed by GC-MS technique. The result of the GC-MS is analyzed using bioinformatics tool for in-silico docking to find out its targets against lung cancer receptors and PDB ID is obtained from the RCBS PDB database. The affinity of the identified ligand molecules to bind to the active site of the protein was studied through docking. And the effectiveness of the ligand molecules was obtained through molecular dynamics for longer simulation. The RMSD, RMSF and RG interaction were studied to the screened compounds. Further, MMPBSA analysis was carried out for the selected and standard drug like irigenin compounds. These selected lead molecules shown the better binding energy compare to irigenin drug in MMPBSA. The lead derivatives have shown 
potential results against lung cancer cell lines.

Keywords- Mimosa pudica, phytochemicals, docking, GCMS, molecular dynamics, MMPBSA.

\section{Introduction}

Plants have been used for their medicinal properties for a very long time. The traditional medicines are always used as a substitute to conventional therapy. Thus, medicinal plants are the main backbone of the traditional medicine due to presence of countless bioactive or phytochemicals compounds. These phytochemicals compounds draw more attention towards the research and to find out the pharmacological activities of medicinal plants. Mostly traditional practitioners use these medicinal plants in rural areas of developing countries of the world. The Indian, sub-continent has a vast and rich diversity of plant species in a wide range of ecosystems and comprises of 2532 plant species which shows medicinal properties(Sharma, Rangra and Tripathi, 2019). One of the most popular system in Indian is form of Ayurvedic medicine, where considered using the traditional medicine plants to treat various infectious diseases. The use of traditional medicine and medicinal plants is more in developing countries, for maintenance of good health, it has been widely observed by UNESCO, 1996. (Ahvazi et al., 2012)

Mimosa pudica L. is a creeping annual or perennial herb, also known by the names Laajvanti, Touch me not, and Chhui-mui. Two well-known movements are observed in M. pudica L. (ojigi-so in Japanese), one is the very rapid movement of the leaves when stimulated by touch, heating, etc., and the other one is very slow with periodical movement of the leaves called nyctinastic movement which is controlled by a biological clock(Genest et al., 2008).This plant is a native of tropical America and naturalized nearly all through the tropical and subtropical parts of India. It has been identified in Ayurveda form, lajjalu has been found to have antiasthmatic, aphrodisiac, analgesic, and antidepressant properties. M. pudica is also known to have sedative, emetic, and tonic properties. It is used in the treatment of various ailments including alopecia, diarrhoea, dysentery, insomnia, tumour, and various urogenital infections. Phytochemical studies on $M$. pudica have revealed the presence of compounds like alkaloids, non-protein amino acid (mimosine), flavonoids C-glycosides, sterols, terpenoids, tannins, and fatty acids(Genest et al., 2008). 
The secondary metabolites is significant in that they are extensively used in the various therapies including antibacterial, antifungal, antinematode, antiviral, anticancer and antiinflammatory activities. The increase in cancer cases would be doubled in the next 20years, as of now 1.45 million cases as by diagnosed by ICMR at Bengaluru, India(Singh M et.al). The paradigm shift has occurred in the cancer research by identifying the appropriate molecular pathways, which involves the cell initiation and progression for developing the therapies according to the molecular profile of the individual patient. This treatment makes more effective then the generalization therapies. Hence, it is an essential to have pharmaceutical potential active compound and as a suitable therapeutic target for the cancer treatment. Phytochemicals have been used for many bases, which includes fewer adverse effects, well tolerated within the body and low cost hence as promising bioactive compounds for prevention, treatment or reversal of drug resistance in cancer (Aliebrahimi et.al). Cancer cells have a behaviour known as metastatic behaviour which is promoted by EDA containing fibronectin in wide variety of cancer types (Xiang, L. et al.,Ou, J. et al.). In lung cancer fibronectin containing EDA plays an important role to induce cell spreading and migration and thus causing metastasis (Rybak et.al). The binding of $\alpha 9 \beta 1$ and $\alpha 4 \beta 1$ integrins to C-C loop within the EDA domain is facilitated by EDGIHEL peptide (Liao et.al). The activation of prooncogenic signalling pathway is mediated by EDA in the cellular fibronectin through $\alpha 9 \beta 1$ integrin which leads to metastasis along with the induction of mesenchymal phenotype and epithelial cells markers which is known as Epithelial-Mesenchymal Transition (EMT) (Ou, J. et al.). In human cancer cells migration is mediated by the EMT pathway so, by targeting the C-C loop region of the EDA domain this pathway can be modulated.

To understand the effectiveness of the bioactive compounds towards the cancer cells the extract was treated against the lung cancer cell lines and the compound library obtained from GC-MS analysis is further screened to obtain the compounds which have affinity towards the C-C loop region of EDA through molecular docking. The shortlisted compound was further screened for its ADMET properties. The obtained complex from the molecular docking was further used for MD simulations for triplicates of 50ns with the previous studied drug irigenin (Amin et.al.).

\section{Materials and Methods}

\section{Plant collection}

Plant samples of Mimosa pudica linn were collected from GKVK, Bengaluru. The plant was authenticated by a botanist a Bangalore University Bengaluru, Karnataka, India. 


\section{Extract preparation}

Leaf sample were shade dried and was made into powder. This powder was then treated with methanol and kept for $72 \mathrm{~h}$ in shaker incubator. Then it was filtered by using Whatman filter No.1. This extract was used for the phytochemical analysis, anti-oxidant, anti-microbial, antiinflammatory and anti-cancer studies and GC-MS analysis to find the bioactive components.

\section{Phytochemical Analysis}

The leaf extract was used for the preliminary screening of phytochemicals such as alkaloids (Wagner's and Meyer's tests), saponins (foam test), tannins (gelatin test), and flavonoids (Alkaline reagent and Lead acetate tests), the screening was done as per the standard method. Phytochemical screening was carried out according to the methods described by (Sree Vidhya and Geetha, 2018).

\section{Antioxidant Activity}

Sample was dissolved in $95 \%$ methanol to make a concentration of $1 \mathrm{mg} / \mathrm{ml}$ and then diluted to prepare the series concentration for antioxidant assays, all of it were compared with reference chemicals.

\section{DPPH Method}

The antioxidant activity of the plant extracts was performed on the basis of the scavenging effect on the stable DPPH free radical activity. The stock solution of $0.1 \mathrm{mM}$ DPPH was prepared freshly in methanol and kept in dark at $40^{\circ} \mathrm{C} .3 \mathrm{ml}$ of different concentration of plant extracts ranging from 0 to 100 were added to DPPH stock solution and incubated at ambient temperature in dark for $20 \mathrm{~min}$. after incubation the absorbance was recorded against blank at $517 \mathrm{~nm}$. Ascorbic acid was used as the standard for antioxidant activity. The same procedure was applied for ascorbic acid which was taken as the standard. The \% of inhibition is calculated by using formula

$\%$ of Inhibition $=\frac{\mathrm{AC}-\mathrm{AS}}{\mathrm{AC}} \times 100$

Where, Ac is absorbance of control. Asis absorbance of sample.

\section{Phosphomolybdenum Assay}

The total antioxidant capacity of the fraction was determined by phosphomolybdate method using ascorbic acid as standard. Plant extracts of different concentration ranging from 0.1- 
$0.5 \mathrm{ml}$ in six test tubes, and -the volume is made up to $1 \mathrm{ml}$ with ethanol. $1 \mathrm{ml}$ of distilled water is taken as blank. The extract was mixed with $1 \mathrm{ml}$ each of reagent solutions $\left(0.6 \mathrm{M} \mathrm{H}_{2} \mathrm{SO}_{4}\right.$, $28 \mathrm{mM}$ sodium phosphate) and $4 \mathrm{mM}$ ammonium molybdate). The reaction mixture was incubated at $95^{\circ} \mathrm{C}$ for 90 minutes and cooled to room temperature. Finally, absorbance was measured at $695 \mathrm{~nm}$ using spectrophotometer against blank. The same procedure was applied for ascorbic acid which is taken as the standard(Haq et al., 2015).

\section{Anti-Inflammatory Activity}

The anti-inflammatory activity was studied by inhibition of albumin denaturation. It is also known as BSA (bovine serum albumin) assay or anti-denaturation assay. Different volumes $(0.1,0.2,0.3,0.4,0.5 \mathrm{ml})$ of sample are taken in test tubes (marked from 1-5). Make up the volume to $1 \mathrm{ml}$ using methanol. Prepare a blank with $1 \mathrm{ml}$ of distilled water and a control with $1 \mathrm{ml}$ of methanol. Add $1 \mathrm{ml}$ of BSA into all the test tubes. Incubate at room temperature for 10 minutes and in water bath at $60^{\circ} \mathrm{c}$ for 10 minutes. Take the O.D. at $660 \mathrm{~nm}$ and calculate the percentage of inhibition(Adarsh Verma et al., 2011).

\section{MTT ASSAY}

Cytotoxicity of sample to lung cancer cells were determined by MTT assay. MTT Assay was performed following protocol(Tim, 1983), Cells were transferred to a centrifuge tube and centrifuged at $3000 \mathrm{rpm}$ for 5 minutes. Pellet was taken and supernatant was discarded. In a 96 well micro titre plate, $150 \mu \mathrm{l}$ of the cell suspension was added and incubated at $37^{\circ} \mathrm{C}$ and $5 \% \mathrm{CO}_{2}$ atmosphere for $24 \mathrm{hr} .100 \mu \mathrm{l}$ of different test concentrations of test drug and standard drug-aspirin were added to the respective wells. The plates were then incubated at $37 \square$ and $5 \% \mathrm{CO}_{2}$ atmosphere for $24 \mathrm{hr} .200 \mu \mathrm{l}$ of medium containing $10 \%$ MTT reagent was then added to each well to get a final concentration of $0.5 \mathrm{mg} / \mathrm{ml}$ and the plates were incubated at $37^{\circ} \mathrm{C}$ and $5 \% \mathrm{CO}_{2}$ atmosphere for $3 \mathrm{hrs}$. The culture medium was removed completely without disturbing the crystals formed $100 \mu 1$ of solubilisation solution was added and the plates were gently shaken to solubilise the formazan formed. The absorbance was measured using a microplate reader at a wavelength of $570 \mathrm{nM}$ and also at $660 \mathrm{nM}$.

GCMS analysis The JEOL GCMATE II GC-MS with data system is a high resolution, double focusing instrument. Maximum resolution: 6000 Maximum calibrated mass: 1500 Daltons. Source options: Electron impact (EI); Chemical ionization (CI).School of Advance sciences, VIT university, Vellore, Tamil Nadu.

\section{Molecular Docking}

In-silico docking for anti-cancerous studies were taken as described by (Rampogu et al., 2019)using Autodock v4.2.6 for noticing interactions of residues obtained from plant extract 
with target C-C loop of EDA (PDB Id: 1J8k). Protein was rigidity was kept while the ligand was flexible during the docking. Based upon the binding affinity the ligands were screened. The docked poses were further anlyzed using pymol for interaction studies.

\section{Molecular Dynamics Simulations}

The docked structure from docking analysis is further used for MD simulations for the better understanding of the drug binding. Prodrug server(A. W. Schüttelkopf and D. M. F. van Aalten (2004)PMID: 15272157), has been used to obtain the topology of the ligand. The molecular dynamics simulation was carried out using GROMACS 4.6 platform. GROMOS 43a1 force field is used, the complex is subjected to energy minimization for 5000 steps and position restraint is performed in NVT and NPT ensembles at $300 \mathrm{~K}$ and 1 atm pressure for 1ns. To validate the data the 50ns simulations was carried out in triplet. GROMACS simulation is used for the analysis of the simulated data. The stability of the backbone atoms was analyzed using root mean square deviation and root mean square fluctuation of C- $\alpha$ atoms is recorded followed by Radius of gyration to understand protein compactness over the 50ns trajectory. Different gromacs utility have been used such gmx_rms, gmx_rmsf and gmx_gyrate.

\section{Free energy calculations (MM-PBSA)}

The calculation of interaction energy between the drug and protein is calculated using Molecular Mechanics Poisson-Boltzmann Surface Area (MM-PBSA) method. Using g_mmpbsa one of the utilities of gromacs, the binding free energy was evaluated (Rashmi et.al.PMID: 24850022, 2014). The binding free energy ( $\Delta$ Gbind) composed of following species:

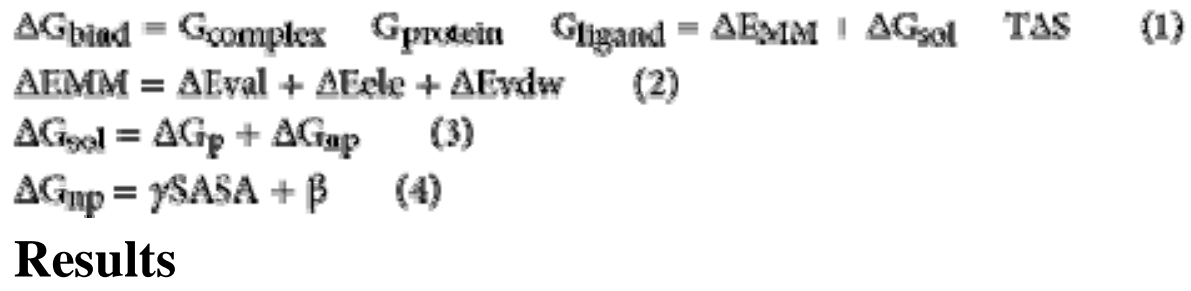

\section{Phytochemical analysis}

Preliminary phytochemical screening of extract of the dried leaves revealed the presence of secondary metabolites like terpenoids, flavonoids, alkaloids, saponins and gelatin etc. and the results are tabulated in table 1.

The present study indicates that the $\mathrm{IC}_{50}$ value of methanolic extract is quite high, as 
compared to the standard. From the figure 1, it is indicated that the $\mathrm{IC}_{50}$ value of methanolic extract were found to be $267.9 \mu \mathrm{g} / \mathrm{ml}$. Hence, it suggests that Mimosa pudica linnshows good antioxidant activity even at lower concentrations as compared to control, ascorbic acid. The phospho-molybdenum method is quantitative since the total antioxidant capacity is express as ascorbic acid equivalents. The results show that Mimosa pudica linn has potent antioxidant activity at higher concentration as compared to ascorbic acid. The $\mathrm{IC}_{50}$ value of methanolic extract was found to be $63.09 \mu \mathrm{g} / \mathrm{ml}$, shown in figure 2 .

In vitro anti-inflammatory activity was performed by BSA denaturation method, the obtained results are shown in figure 3 . The methanolic extract of the plant leaves shows the $\mathrm{IC}_{50}$ value of $318.4 \mu \mathrm{g} / \mathrm{ml}$, compared to standard diclofenac.

\section{MTT Assay}

The MTT assay reveals about the cell viability. The inhibitory effect of leaf methanolic extract on cancer cell line is observed when the concentration was taken $1.5 \mathrm{mg} / \mathrm{ml}$ the $\mathrm{IC}_{50}$ value thus obtained does not had a satisfactory result the increased concentration could provide a satisfactory $\mathrm{IC}_{50}$ value.

\section{GC-MS Analysis}

GC-MS analysis showed presence of 11 phytochemical in the extract which is illustrated in table 2.

\section{Molecular docking}

In order to identify a prospective candidate for metastasis stage of lung cancer, molecular docking was executed over 11 phytoconstituents acquired from leaf of Mimosa pudica linn $\mathrm{n}$ on the binding pocket of EDA domain (PDB ID: 1J8K). From the literature it was clearly indicated thatmetastatic behaviour of the cancer cell is mediated by EDA domain. Docking score of all the 11 compounds along with the compound irigenin is illustrated in table 3 . Those active molecules possess dock score value of 7.0 or more were picked for further studies. Total of 2 compounds was selected based on the binding interactions with $1 \mathrm{~J} 8 \mathrm{~K}$. Out of the 2 compounds, alpha-Methylglucofuranoside(AMM) exhibited the bestdocked score (7.1 Kcal/mol) with $1 \mathrm{~J} 8 \mathrm{~K}$ and 1,3-dioxolane-2-propanal, 2-methyl( DPM) exhibited the docked score $(-7.0 \mathrm{Kcal} / \mathrm{mol})$ and the irigenin (IRI) exhibited the dock score of ( -6.5 $\mathrm{Kcal} / \mathrm{mol})$.

\section{MD simulation}


A set of three simulations of 50ns for each of the complex is performed. Followed by the different analysis RMSD analysis gives insights and variations in terms of the stability and to confirm that the system has been equilibrated or not. The RMSD plot of the backbone atoms for the apo protein (without ligand) and the complex with IRI, AMM and DPM is shown in Figure - 6. The protein structure with the compound AMM is found to be more stable as compared to the other complex system over the 50ns simulation.

RMSF calculates the fluctuation of each residues over the simulation. The interaction energy of the ligands with the protein is directly linked with the RMSF fluctuations. The RMSF values for each of the complex and the apo protein is shown in figure - 7. The RMSF shows that the more of the fluctuations occurred in the loop region of the protein which indicates that the protein did not fluctuated over the 50ns simulation period.

To understand the affect of the ligand on the compactness of the protein RG was performed and showed in the figure - 8. The compactness of the protein is not hampered in the $50 \mathrm{~ns}$ simulation for all the complexes as well as compared to the apo protein.

We have reported that the binding energy values of the $1 \mathrm{~J} 8 \mathrm{~K} \_\mathrm{AMM}$ is found to be -62.468 +/- $12.613 \mathrm{KJ} / \mathrm{mol}$ and for complex 1J8K_DPM -42.012 +/- $6.372 \mathrm{KJ} / \mathrm{mol}$ and for 1J8K_IRI Is found to be $-28.688+/-11.354 \mathrm{KJ} / \mathrm{mol}$ this indicates that the compound AMM is having higher affinity towards the receptor. These complexes were further submitted to the residue wise MM-PBSA energy value calculations in which the hotspot interactions for the complex 1J8K_AMM are: ASP-41 -4.471 kcal/mol, HIS-44 -1.25 kcal/mol, GLU-40 -5.9 kcal/mol, and SER-38 -3.09 kcal/mol, for the complex 1J8K_DPM the hotspot interactions are: GLU$40-8.82 \mathrm{kcal} / \mathrm{mol}$, ASP-41 -1.35 kcal/mol, and ALA-94 -7.24 kcal/mol. The MD trajectories showed that the compound AMM and DPM are having more affinity towards the fibronectin EDA domain. 


\section{Discussion}

Mimosa pudica linn is well known for its herbal properties throughout the world. Many studies have proven the beneficial and pharmacological efficiency of the M.pudica, Jose et., al. (2014) and having potential anticancer activity. But the greatest challenge in phytochemical and pharmacological studies is that it requires identification of specific compounds which are responsible for beneficial effects and there mode of action and thus relieving their usefulness as a therapeutic drug.

Different phytochemical analysis revels that the methanolic leaf extract of the plant consist of Alkaloids, terpenoids, flavonoids and saponins. DPPH assay have been used to evaluate its free radical scavenging activity of the natural antioxidant. The reaction depends upon the hydrogen donating ability of the antioxidants (Chen $\mathrm{CW}$ et.al). The extract showed potent free radical scavenging activity with $\mathrm{IC}_{50}$ value of $267.9 \mu \mathrm{g} / \mathrm{ml}$ respectively. This suggests that it can react with the free radicals and can convert them into more stable products and thus terminate radical chain reaction. The extract also showed the anti-inflammatory activity with the $\mathrm{IC}_{50}$ value of $318.4 \mu \mathrm{g} / \mathrm{ml}$.

In this study, the methanolic extract of Mimosa pudica linn was used to evaluate the possible anticancer activity. The cytotoxic activity was monitored by MTT assay. This test depends upon the mitochondrial activity per cell and number of cells presents. The cleavage of MTT to a blue formazan derivative confirms the decrease in survival of the cultured cell.

The metastatic behaviour of the cancer cells makes it more dangerous so, further in this study we performed computational analysis to understand the effect of each compounds obtained from the GC-MS analysis in the inhibition of the EMT pathway as discussed in introduction which is responsible for the metastatic behaviour of the cancer cells. The EDA domain is targeted in this study with PDB id: $1 \mathrm{~J} 8 \mathrm{~K}$ and is compared with the previously known potential inhibitor irigenin (Amin et.al.).. From initial docking analysis we found the compounds alpha-Methylglucofuranosideand 1,3-dioxolane-2-propanal, 2-methylhave higher efficiency towards the protein target amongst the 11-compound obtained through GC-MS analysis. Further MD simulations of 50ns were carried out to understand the protein stability and the binding efficiency of the ligand towards the protein target. From the RMSD, RMSF and RG analysis it was observed that the protein structure was stable in the presence of the compound. Further, interaction energy reveals the binding efficiency of the two compounds $\mathrm{AMM}$ and DPM is much efficient then the Irigenin and per residue interaction reveals a much stable binding between the ligand and the proteins. Further the efficiency of the two compounds can be proved by its in-vitro, in-vivo and clinical studies. 


\section{Acknowledgement:}

Authors would like to extend their gratitude to Department of biotechnology, The Oxford college of science HSR Bangalore for providing support and aid for the study and VIT Vellore for performing GC- MS analysis.

\section{References:}

Adarsh Verma, M. et al. (2011) 'Anti denaturation and antioxidant activities of Annona cherimola invitro', International Journal of Pharma and Bio Sciences, 2(2), pp. 1-6.

Ahvazi, M. et al. (2012) 'Introduction of medicinal plants species with the most traditional usage in Alamut region', Iranian Journal of Pharmaceutical Research, 11(1), pp. 185-194. doi: 10.22037/ijpr.2011.1018.

Singh M, Prasad CP, Singh TD, Kumar L. Cancer research in India: Challenges \& opportunities. Indian J Med Res 2018;148:362-5

Aliebrahimi, S., Montasser Kouhsari, S., Ostad, S. et al. Identification of Phytochemicals Targeting c-Met Kinase Domain using Consensus Docking and Molecular Dynamics Simulation Studies. Cell Biochem

Biophys 76, 135-145 (2018). https://doi.org/10.1007/s12013-017-0821-6

Genest et al. (2008) 'Comparative bioactivity of two Mimosa species', Lat Am Caribb Bull Med Aromat Plants, 7, pp. 38-43.

Haq, I. ul et al. (2015) 'A rapid and sensitive method for the quantitation of microgram quantities of protein utilizing the principle of protein-dye binding.', World journal of microbiology \& biotechnology, 31(11), pp. 248-254. doi: 10.2172/1023318.

Rampogu, S. et al. (2019) 'Pharmacotherapeutics and molecular mechanism of phytochemicals in alleviating hormone-responsive breast cancer', Oxidative Medicine and Cellular Longevity, 2019. doi: $10.1155 / 2019 / 5189490$.

Sarker, S. D., Nahar, L. and Kumarasamy, Y. (2007) 'Microtitre plate-based antibacterial assay incorporating resazurin as an indicator of cell growth, and its application in the in vitro antibacterial screening of phytochemicals', Methods, 42(4), pp. 321-324. doi: 10.1016/j.ymeth.2007.01.006.

Sharma, I., Rangra, A. and Tripathi, A. (2019) 'Annals of Pharmacology and Pharmaceutics Comparative Analysis of Antimicrobial, Antioxidant and Phytochemicals from the Folk Medicinal Plants of', 4(1).

Sree Vidhya, T. M. and Geetha (2018) 'In vitro evaluation of anti-inflammatory activity of Andrographis paniculata', Research Journal of Pharmacy and Technology, 11(3), pp. 957-958. doi: 10.5958/0974-360X.2018.00178.6.

Tim, M. (1983) 'Rapid Colorimetric Assay for Cellular Growth and Survival $\square$ : Application to 
Proliferation and Cytotoxicity Assays', Journal of Immunological Methods, 65, pp. 55-63.

Xiang, L. et al. The extra domain A of fibronectin increases VEGF-C expression in colorectal carcinoma involving the PI3K/AKT signaling pathway. Plos ONE 7, e35378, doi: 10.1371/journal.pone.0035378 (2012).

$\mathrm{Ou}$, J. et al. Fibronectin extra domain A (EDA) sustains CD133+/CD44+ subpopulation of colorectal cancer cells. Stem cell research 11, 820-833, doi: 10.1016/j.scr.2013.05.009 (2013).

Rybak, J. N., Roesli, C., Kaspar, M., Villa, A. \& Neri, D. The Extra-domain A of Fibronectin Is a Vascular Marker of Solid Tumors and Metastases. Cancer Research 67, 10948-10957, doi: 10.1158/0008-5472.can-071436 (2007).

Liao, Y.-F., Gotwals, P. J., Koteliansky, V. E., Sheppard, D. \& Van De Water, L. The EIIIA Segment of Fibronectin Is a Ligand for Integrins $\alpha 9 \beta 1$ and $\alpha 4 \beta 1$ Providing a Novel Mechanism for Regulating Cell Adhesion by Alternative Splicing. Journal of Biological Chemistry 277, 14467-14474, doi:

10.1074/jbc.m201100200 (2002).

$\mathrm{Ou}$, J. et al. Endothelial cell-derived fibronectin extra domain A promotes colorectal cancer metastasis via inducing epithelial-mesenchymal transition. Carcinogenesis, doi: 10.1093/carcin/bgu090 (2014).

Amin, A., Chikan, N., Mokhdomi, T. et al. Irigenin, a novel lead from Western Himalayan chemiome inhibits Fibronectin-Extra Domain A induced metastasis in Lung cancer cells. Sci Rep 6, 37151 (2016).

https://doi.org/10.1038/srep37151

Jose J, Sudheesh S, Sumesh Kumar TM, Sony J, Jayadevi Variyar E. A comparative evaluation of anticancer activities of flavonoids isolated from Mimosa pudica, Aloe vera, Phyllanthus niruri against human breast carcinoma cell line (MCF-7) using MTT assay. Int J Pharm Pharm Sci 2014;6:319-22.

Chen CW, Ho CT. Antioxidant properties of polyphenols extracted from green and black teas. J Food Lipids 1995;2:35-46. 
bioRxiv preprint doi: https://doi.org/10.1101/2021.07.30.454465: this version posted August 1, 2021. The copyright holder for this preprint (which was not certified by peer review) is the author/funder, who has granted bioRxiv a license to display the preprint in perpetuity. It is made available under aCC-BY 4.0 International license.

Figure : 1 Antioxidant activity by Phosphomylbdenum assay

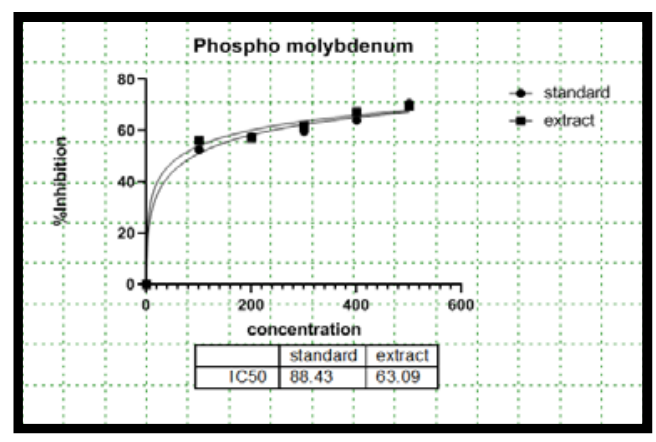


bioRxiv preprint doi: https://doi.org/10.1101/2021.0730.454465; this version posted August 1, 2021. The copyright holder for this preprint (which was not certified by peer review) is the author/funder, who has granted bioRxiv a license to display the preprint in perpetuity. It is made available under aCC-BY 4.0 International license.

Figure : 2 Antioxidant activity by DPPH assay

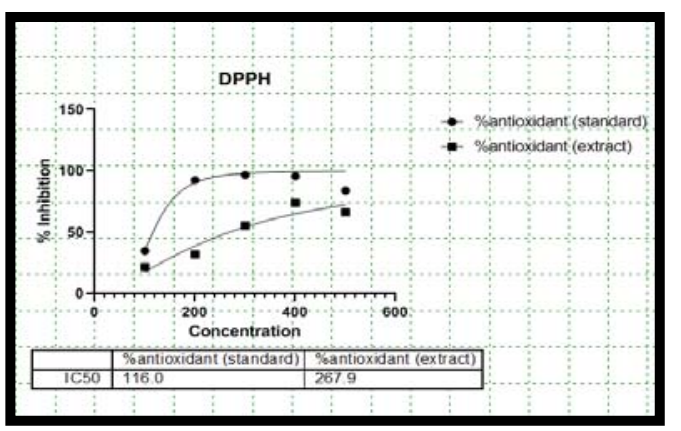




\section{Figure :3 Anti-Inflammatory Activity}

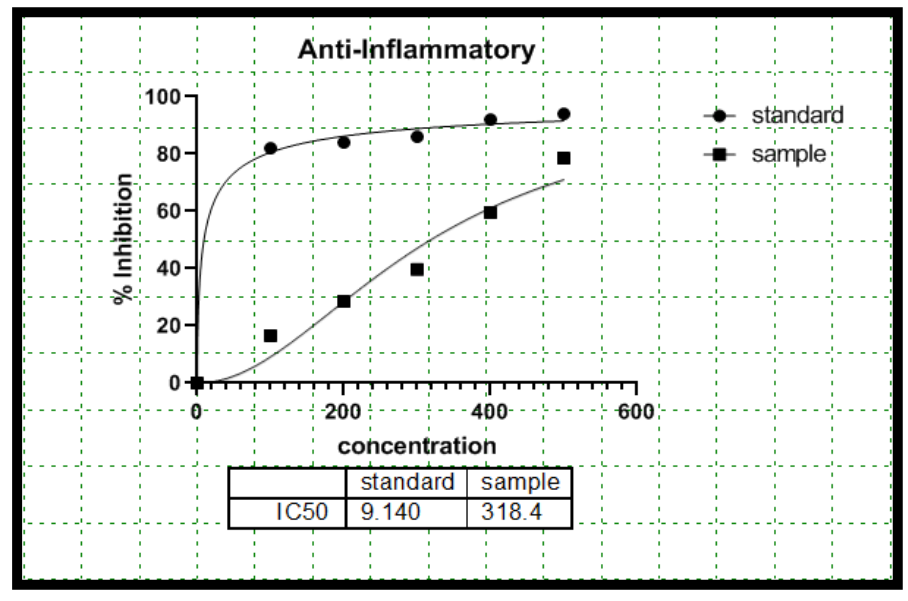


Figure: 4 MTT assay of methanolic extract of Mimosa pudica linn

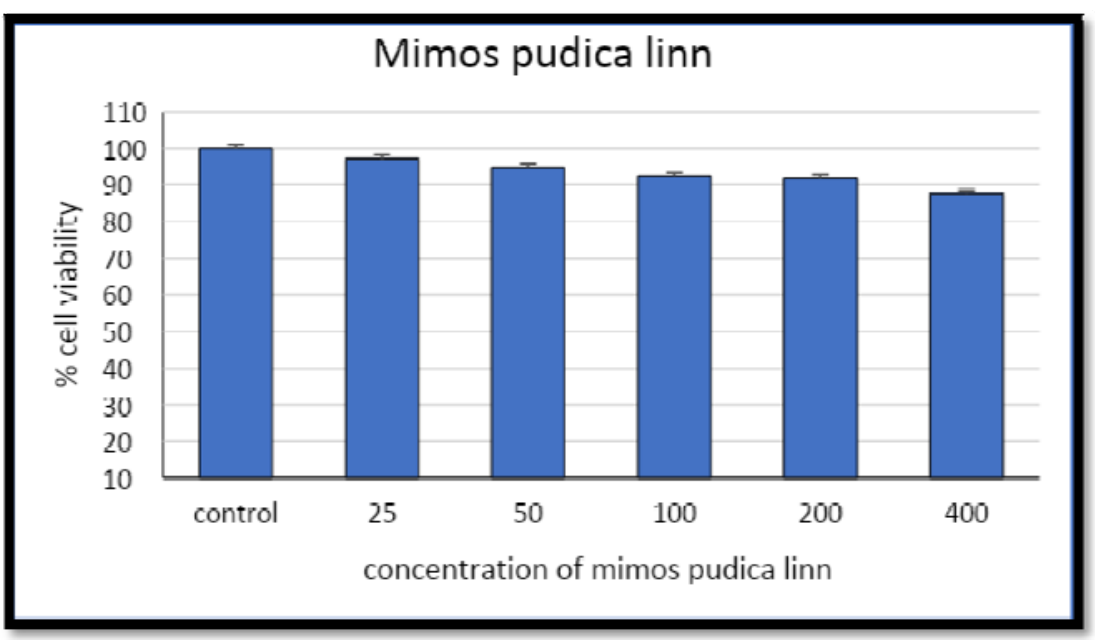


bioRxiv preprint doi: https://doi.org/10.1101/2021.07.30.454465; this version posted August 1, 2021. The copyright holder for this preprint (which was not certified by peer review) is the author/funder, who has granted bioRxiv a license to display the preprint in perpetuity. It is made available under aCC-BY 4.0 International license.

Figure: 5 Chromatogram

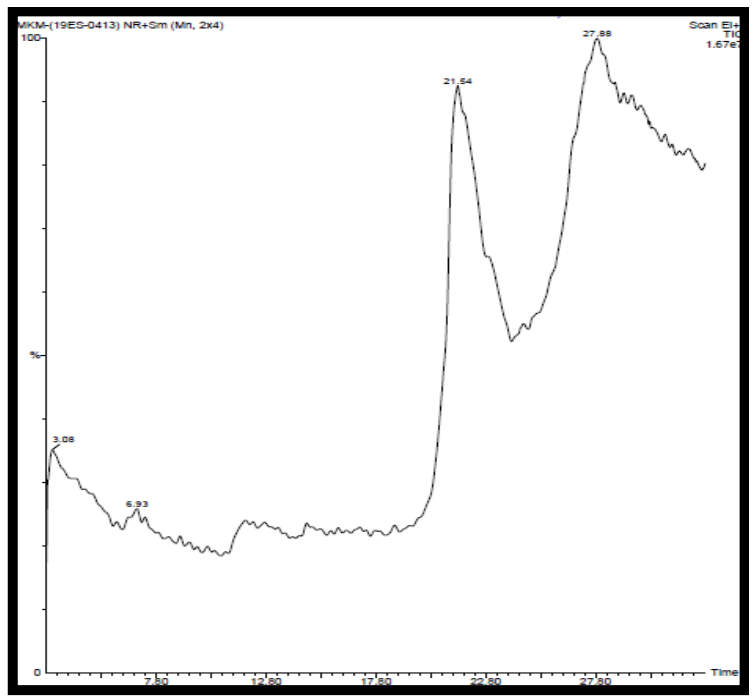


Figure: 6 RMSD plot for respective complexes

\section{RMSD}

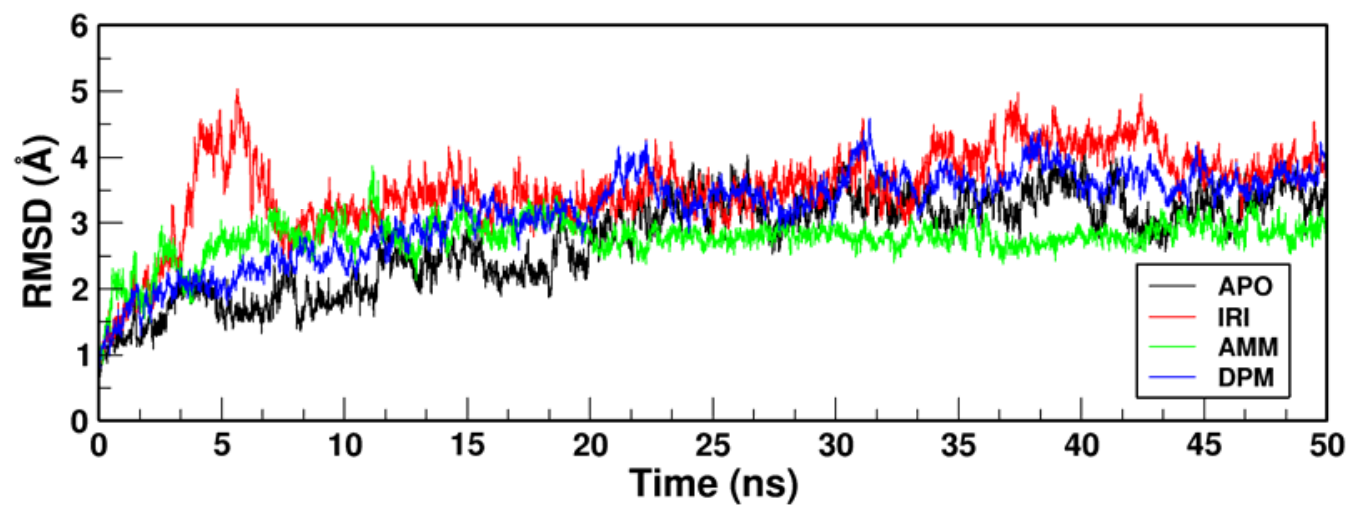


Figure: 7 RMSF plot for respective complexes

\section{RMS fluctuation}

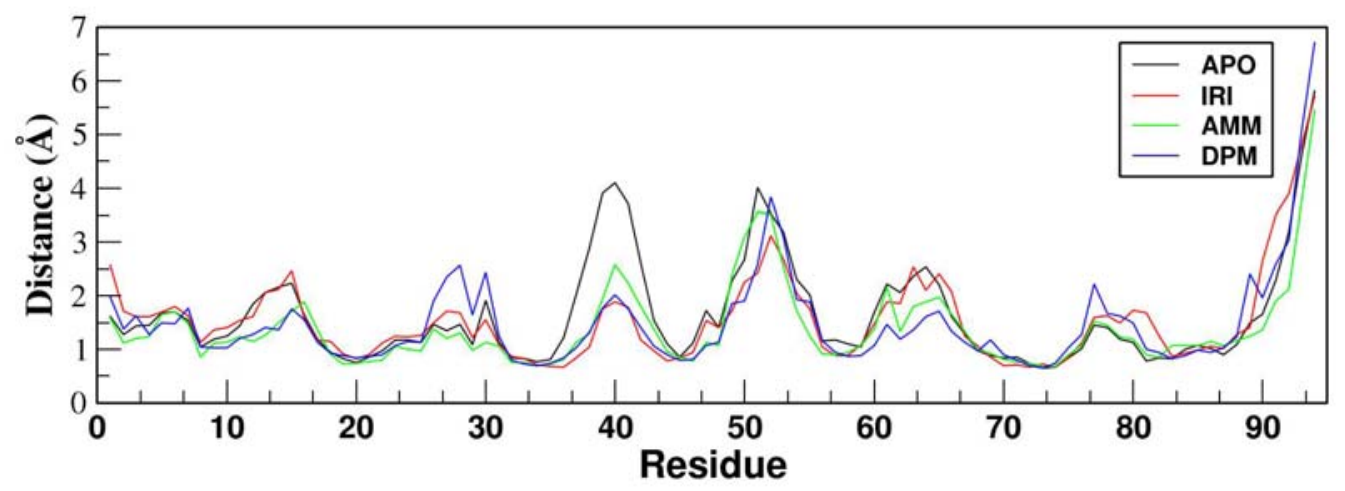


Figure: 8 Radius of gyration plot for respective complexes

\section{Radius of gyration}

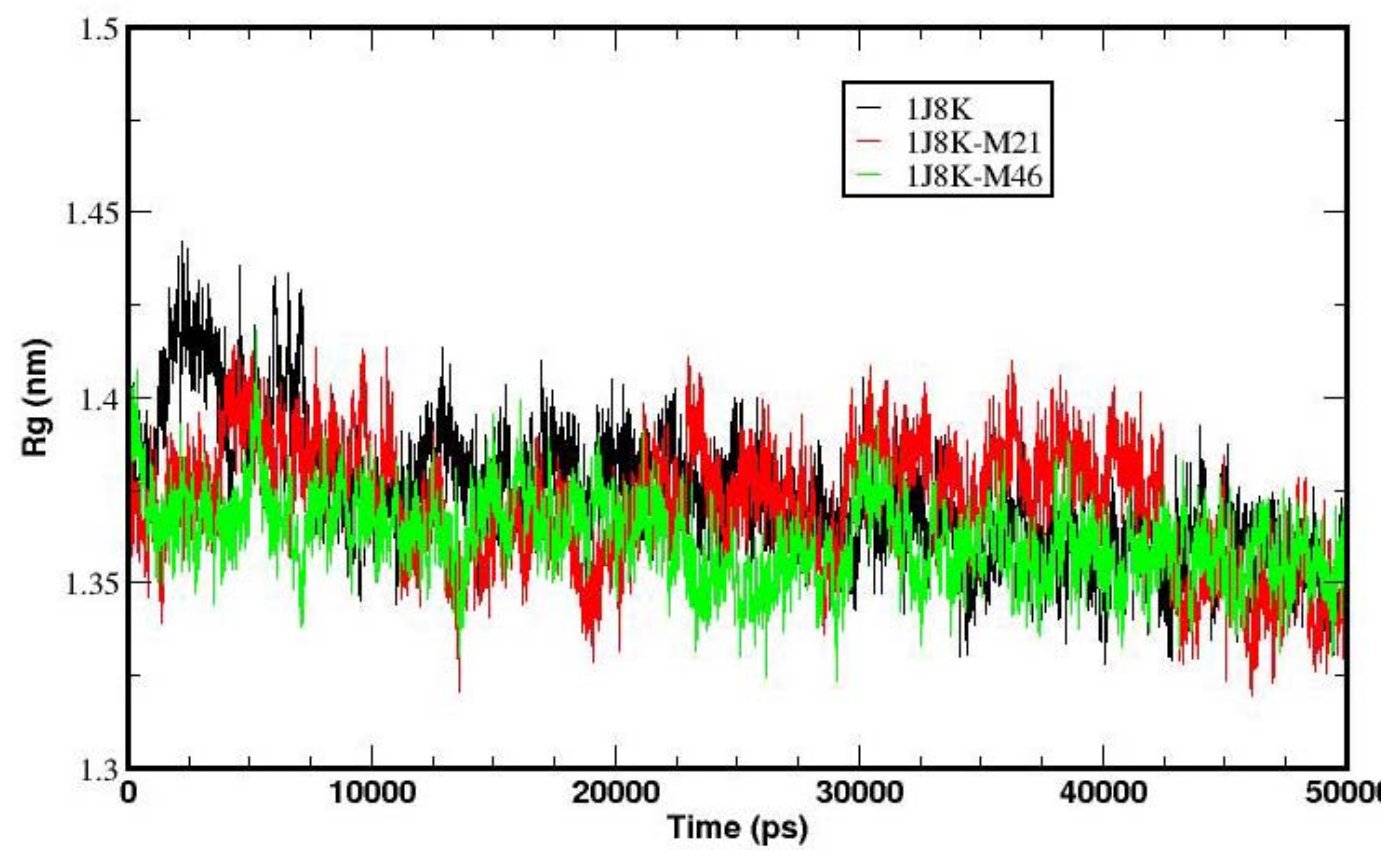


Table: 2 Library output of GCMS ligands from the methanolic extract of Mimosa pudica Linn

\begin{tabular}{|c|c|c|c|}
\hline$\underline{\text { S.no }}$ & $\begin{array}{l}\text { COMPOUND } \\
\underline{\text { (ligand })}\end{array}$ & STRUCTURE & **Activity \\
\hline 1. & $\begin{array}{l}\text { Ala-. beta. -ala, } \\
\text { trimethylsilyl ester }\end{array}$ & & $\begin{array}{l}\text { Anti amyloid } \\
\text { andergenic }\end{array}$ \\
\hline 2. & $\begin{array}{l}\text { alpha- } \\
\text { Methylglucofuranoside }\end{array}$ & но- & $\begin{array}{l}\text { Anticancer } \\
\text { Antidote }\end{array}$ \\
\hline 3. & Meglumine & & $\begin{array}{l}\text { Andergenic } \\
\text { Beta- } \\
\text { Galactosidase- } \\
\underline{\text { Inhibitor }}\end{array}$ \\
\hline 4. & $\begin{array}{l}\text { 1,3-dioxolane-2- } \\
\text { propanal, 2-methyl }\end{array}$ & & $\begin{array}{l}\text { No activity } \\
\text { reported }\end{array}$ \\
\hline 5. & 2-Acetamidoacrylic acid & & $\begin{array}{l}\text { Acidulant } \\
\text { Acidifier }\end{array}$ \\
\hline 6. & N-BUTYLUREA & & $\begin{array}{l}\text { Anaphylactic } \\
\text { Antitumor }\end{array}$ \\
\hline
\end{tabular}




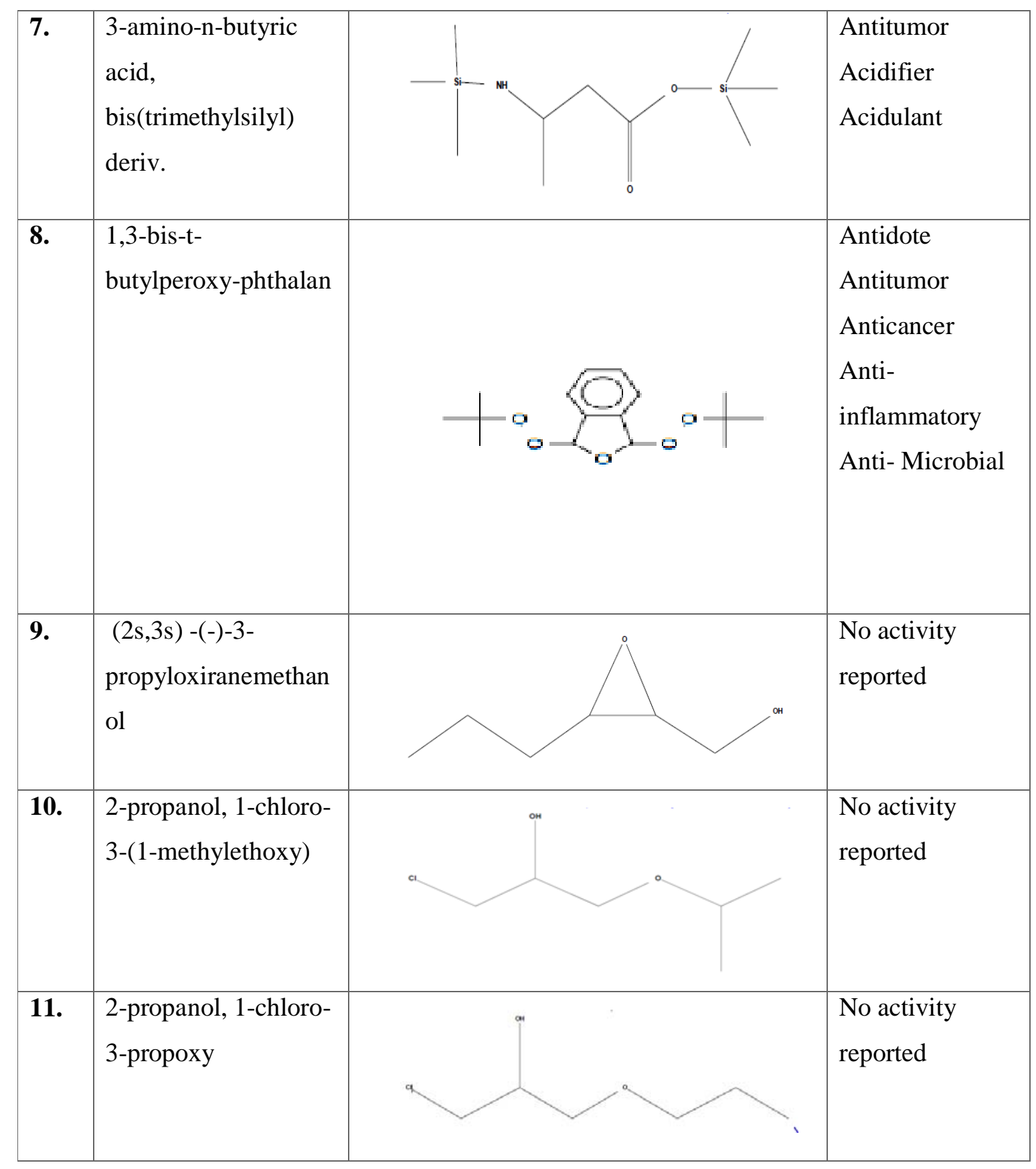

**Source: - Dr.Duke's Phytochemical and Ethnobotanical Databases 


\begin{tabular}{|c|c|c|c|}
\hline S.no. & Compounds & $\begin{array}{c}\text { Binding affinity, } \Delta \\
(\text { Kcal/mol })\end{array}$ & \multirow{13}{*}{$\begin{array}{l}\text { Table: } 3 \\
\text { Interactio } \\
\text { n energy } \\
\text { of ligands } \\
\text { with } \\
\text { Fibronecti } \\
\text { n EDA } \\
\text { domain }\end{array}$} \\
\hline 1. & Ala-. Beta. -ala, trimethylsilyl ester & -4.9 & \\
\hline 2. & alpha-Methylglucofuranoside & -7.1 & \\
\hline 3. & Meglumine & -5.5 & \\
\hline 4. & 1,3-dioxolane-2-propanal, 2-methyl & -7.0 & \\
\hline 5. & 2-Acetamidoacrylic acid & -5.3 & \\
\hline 6. & N-BUTYLUREA & -4.3 & \\
\hline 7. & 3-amino-n-butyric acid, bis(trimethylsilyl) deriv & -5.6 & \\
\hline 8. & 1,3-bis-t-butylperoxy-phthalan & -5.8 & \\
\hline 9. & $(2 s, 3 s)-(-)-3$-propyloxiranemethanol & -4.2 & \\
\hline 10. & 2-propanol, 1-chloro-3-(1-methylethoxy) & -3.3 & \\
\hline 11. & 2-propanol, 1-chloro-3-propoxy & -6.1 & \\
\hline 12. & Irigenin & -6.5 & \\
\hline
\end{tabular}


Table :1 Screening of secondary metabolites

\begin{tabular}{lc}
\hline Secondary metabolites & Result \\
\hline Alkaloids & ++ \\
Carbohydrates & ++ \\
Phytosterol & -- \\
Resin & -- \\
Phenol & -- \\
Tannin & -- \\
Saponins & ++ \\
Terpinoids & ++ \\
Flavanoids & ++ \\
\hline
\end{tabular}

